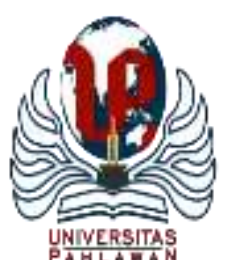

\title{
JURNALBASICEDU
}

Volume 6 Nomor 1 Tahun 2022 Halaman 276 - 286

Research \& Learningin Elementary Education https://jbasic.org/index.php/basicedu

\section{Analisis Kendala Orang Tua dalam Mendampingi Anak Selama Pembelajaran Daring di Madrasah Ibtidaiyah}

\author{
Maulia Isna Choirunisa ${ }^{1}$, Zaenal Abidin ${ }^{2}$ \\ Pendidikan Guru Sekolah Dasar, Universitas Muhammadiyah Surakarta, Indonesia ${ }^{1,2}$ \\ E-mail: Mauliaisna1999@gmail.com ${ }^{1}, \underline{z a 825 @ u m s . a c . i d ~}^{2}$
}

\begin{abstract}
Abstrak
Penelitian ini memiliki tujuan untuk mendeskripsikan kendala orang tua saat mendampingi anak belajar daring yang terjadi di MI Al Maarif Doyo dan mencari solusinya. Subjek pada penelitian adalah orang tua, kepala sekolah dan guru di MI Al Maarif Doyo. Penelitian ini menggunakan pendekatan kualitatif deskriptif. Metode pengumpulan data melalui observasi, wawancara, angket dan dokumentasi. Teknik analisis data dengan menggunakan analisis deskriptif. Data dari hasil penelitian diuji kembali keabsahan data dengan memperpanjang keikutsertaan, menekuni pengamatan dan triangulasi. Hasil penelitian menunjukkan bahwa kendala yang dihadapi oleh orang tua saat mendampingi anak belajar secara daring yaitu : anak tidak mood dan jenuh belajar, kendala kesibukan orang tua, kendala dalam kurangnya pemahaman materi pelajaran dan kendala jaringan handphone. Sementara itu solusi yang diberikan adalah menerapkan sistem punishment and reward, memberikan permainan yang menarik, dan selalu mendampingi dan menasehati anak serta mengundang guru bimbel untuk mendampingi anak belajar dan untuk jaringan dengan cara mengganti kartu yang sesuai.
\end{abstract}

Kata Kunci : Pembelajaran Online, Kendala, Orang Tua

Abstract

This study aims to describe the obstacles parents face when assisting children in online learning that occurs at MI Al Maarif Doyo and find solutions. The subjects in this study were parents, principals and teachers at MI Al Maarif Doyo. This study uses a descriptive qualitative approach. Methods of data collection through observation, interviews, questionnaires and documentation. Data analysis technique using descriptive analysis. The data from the research results were re-tested for the validity of the data by extending participation, pursuing observations and triangulation. The results showed that the obstacles faced by parents when accompanying their children to learn online were: children were not in the mood and bored with studying, the constraints of busy parents, obstacles in the lack of understanding of the subject matter and the constraints of the mobile phone network. Meanwhile, the solution provided is to implement a punishment and reward system, provide interesting games, and always accompany and advise children and invite tutoring teachers to accompany children to learn and to network by changing the appropriate card.

Keyword : Learning, Online, Problem, Parents

Copyright (c) 2022 Maulia Isna Choirunisa, Zaenal Abidin

$\triangle$ Corresponding author :

Email : Mauliaisna1999@gmail.com

DOI : https://doi.org/10.31004/basicedu.v6i1.1864

ISSN 2580-3735 (Media Cetak)

ISSN 2580-1147 (Media Online)

Jurnal Basicedu Vol 6 No 1 Tahun 2022

p-ISSN 2580-3735 e-ISSN 2580-1147 


\section{PENDAHULUAN}

Dengan penyebaran virus corona menyebabkan dampak di berbagai bidang kehidupan baik dari bidang ekonomi, sosial maupun pendidikan. Karena adanya pembatasan interaksi, Kementerian Pendidikan RI juga mengeluarkan Edaran Nomor 15 Tahun 2020 tentang Pedoman Penyelenggaraan Belajar Dari Rumah Dalam Masa Darurat Penyebaran Covid-19' dimana surat tersebut berisi mengenai kebijakan untuk mengganti proses pembelajaran dengan sistem belajar di rumah (online) atau juga sering disebut daring (pembelajaran dalam jaringan). Pembelajaran online adalah pembelajaran yang menggunakan internet sebagai tempat penyebaran ilmu pengetahuan. Bentuk pembelajaran ini dapat dilakukan kapan saja, di mana saja, tanpa terikat waktu, dan tanpa harus tatap muka. Di era perkembangan teknologi pembelajaran online semakin kompleks, dengan berbagai aplikasi dan fungsi untuk memudahkan pengguna (Syarifudin, 2020, p. 1).

Adanya pelaksanaan pembelajaran online dalam pelaksanaanya menimbulkan berbagai kendala yang dihadapi oleh siswa dan guru seperti materi yang belum diselesaikan oleh guru, kemudian guru menggantinya dengan tugas lain. (Siahaan, 2020, p. 2). Dengan pelaksanaan pembelajaran online, maka anak atau siswa akan belajar di rumah tanpa bertatap muka dengan guru di sekolah. Berdasarkan kondisi tersebut peran guru secara otomatis akan digantikan oleh orang tua saat di rumah, walaupun tetap saja dalam penyampaian materi pembelajaran tetap diajarkan oleh guru secara online. Akan tetapi untuk peran membimbing dan mendampingi anak belajar menjadi peran yang harus dilaksanakan oleh orang tua saat di rumah. Melalui pembelajaran online, peran orang tua dapat dilakukan dengan mendampingi anaknya belajar di rumah. Selama pandemi virus corona, peran orang tua sangat penting untuk pendidikan anak. Pendidikan yang kurang menyebabkan anak gagal dalam belajar. Di sisi lain, orang tua yang selalu memperhatikan anaknya terutama kegiatan belajar di rumah akan membuat anak lebih proaktif dalam belajar, karena mereka tahu tidak hanya untuk maju sendiri, tetapi juga kepada orang tuanya juga memiliki keinginan yang kuat untuk menjadikan hasil belajar anak lebih baik (Cahyati \& Kusumah, 2020, p. 153). Adapun beberapa peran orang tua yang dimaksud seperti memastikan dan menjaga anak untuk hidup sehat dan bersih, mendampingi anak saat sekolah, melakukan sosialiasasi di rumah, memberikan komunikasi yang dekat dengan anak, memberikan teladan bagi anak dan mengawasi kepada anggota keluarga untuk memenuhi kebutuhan keluarga, memberikan pendidikan, membimbing dan memotivasi anak, memelihara nilai agama, melakukan kreasi dan inovasi kegiatan di rumah (Kurniati, Nur Alfaeni, \& Andriani, 2020, p. 253). Adapun peran secara khusus yang dilaksanakan orang tua dalam pembelajaran online adalah dengan berkoordinasi dengan guru mengenai tugas dan materi pembelajaran yang diberikan kepada anak atau siswa melalui grup whatsapp. Kegiatan koordinasi yang dilakukan orang tua dengan guru adalah melaksanakan monitoring kegiatan anak, mengirimkan tugas anak baik dengan mengirimkan foto atau video, dan melaksanakan evaluasi belajar (Fransiska, 2020, p. 23-24). Secara umum dalam penerapannya di lapangan, pembelajaran daring dilakukan dengan menggunakan handphone melalui platform aplikasi tertentu seperti whatsapp, zoom meeting, google classroom dan masih banyak lagi. Saat memberikan tugas melalui whatsapp group perlu diadakanya pemantauan oleh guru untuk memastikan anak benar - benar belajar dengan berinteraksi dengan orang tua dengan cara mengirimkan foto atau video call (Dewi, 2020, p. 58). Dari peran tersebut, menunjukkan pentingnya orang tua dalam mendampingi anak belajar daring, maka dari itu idealnya dalam pendampingan pembelajaran daring orang tua dapat mendampingi anak belajar dengan lancar tanpa kendala yang berarti.

Akan tetapi dalam menjalankan tugasnya, orang tua dihadapkan pada berbagai masalah atau kendala seperti mengeluarkan banyak uang untuk membeli kuota data, orang tua merasa kesulitan pemahaman materi pembelajaran karena kurangnya penjelasan, anak lebih mempercayai guru dari pada orang tua, orang tua merasa tertekan, dan fasilitas belajar yang terbatas (Sabiq, 2020, p. 14-15). Selain itu, hasil referensi penelitian yang relevan menunjukkan bahwa pada masa pandemi Covid-19 kendala orang tua dalam mendampingi anaknya belajar di rumah biasanya adalah pemahaman orang tua yang kurang memadai 
terhadap materi pelajaran di sekolah, orang tua sulit menumbuhkan minat belajar anak dan tidak cukup waktu untuk mendampingi anaknya saat belajar di rumah hal ini dikarenakan orang tua harus bekerja, orang tua kurang sabar dengan anaknya saat belajar di rumah, orang tua kesulitan mengoperasikan gawai dan kendala lain yang terkait jangkauan layanan internet (Wardani \& Ayriza, 2020, p. 780). Kendala tersebut banyak dirasakan oleh banyak orang tua siswa seperti yang terjadi di MI Al Maarif Doyo berdasarkan hasil wawancara tidak terstruktur menunjukkan bahwa mayoritas orang tua mengeluh akan kendala atau masalah yang dihadapi saat mendampingi anaknya belajar di rumah. Kendala yang dihadapi masing - masing orang tua berbeda - beda. Ada yang kendala dari sisi fasilitas belajar, ada juga yang mengalami kendala dalam mengajarkan dan menyampaikan materi yang diajarkan gurunya kepada siswa serta masih banyak lagi kendala yang dihadapi oleh orang tua. Apabila kondisi tersebut dibiarkan terus - menerus, maka orang tua tidak dapat mendampingi anak belajar dengan maksimal, dan ini nantinya akan berdampak pada kurangnya pemahaman anak terhadap materi pembelajaran. Maka dari itu perlu adanya analisis dan upaya pemecahan masalah dari kondisi tersebut. Melalui penelitian ini, penulis mencoba untuk menganalisis kendala yang dihadapi oleh orang tua selama mendampingi anaknya saat pembelajaran online, selain itu penulis juga akan mencari upaya ataupun alternatif untuk meminimalisir kendala tersebut agar orang tua dapat mendampingi anaknya belajar dengan maksimal. Sehingga kemampuan anak baik dari segi kognitif, afektif maupun psikomotorik dapat berkembang dengan optimal walaupun pembelajaran yang dilakukan saat ini adalah pembelajaran daring. Adapun kebaruan dari penelitian ini dibandingkan penelitian sebelumnya adalah kebaharuan dari penelitian ini adalah peningkatan jumlah indikator dalam menganalisis permasalahan yang dihadapi orang tua dalam mendampingi anak belajar daring. Pada penelitian dahulu belum membahas tentang beberapa indikator yang disusun secara spesifik mengenai kendala yang mungkin terjadi dalam pelaksanaan pembelajaran daring. Maka dari itu penelitian ini penting untuk dilakukan dalam rangka untuk mengetahui dan menemukan alternatif solusi serta dapat mengembangkan penelitian terdahulu.

\section{METODE PENELITIAN}

Penelitian ini menggunakan jenis penelitian deskriptif kualitatif yaitu bertujuan untuk menggambarkan atau mendeskripsikan fenomena atau keadaan secara objektif atau apa adanya. Penelitian ini lebih menekankan pada analisis pada penyimpulan dengan menggunakan logika ilmiah. Populasi penelitian ini adalah seluruh orang tua di MI Al Maarif Doyo dengan diambil sampel sebanyak 9 orang tua siswa kelas atas. Dengan teknik pengambilan sampel simple random sampling yaitu mengambil sampel sederhana secara acak. Adapun teknik pengumpulan data menggunakan observasi, wawancara, angket dan dokumentasi. Analisis data yang digunakan dalam penelitian ini menggunakan analisis model interaktif (Miles dan Huberman) dengan langkah yang pertama adalah koleksi data. Pada tahap ini peneliti mengumpulkan data dengan observasi, wawancara, angket kepada informan yakni orang tua, kepala sekolah dan guru dalam proses penggalian data dengan menggunakan instrument yang sudah dipersiapkan sebelumnya dengan beberapa indikator. Kemudian tahap berikutnya adalah reduksi data. Pada tahap ini, peneliti menyortir data dan informasi yang diperoleh dari hasil penelitian untuk dianalisis faktor penyebab dan solusinya dengan memperhatikan keabsahan data triangulasi metode dan triangulasi sumber. Setelah data di reduksi dan kebsahan sesuai dengan teknik yang digunakan. Kemudian langkah berikutnya peneliti menampilkan data atau sering disebut display data. Pada tahap ini peneliti menampilkan data berupa table dan grafik hasil penelitian. Pada tahap terakhir disebut verifikasi data, pada tahap ini peneliti menarik kesimpulan dari beberapa kendala yang dihadapi orang tua dalam mendampingi anak selama pembelajaran daring. 
DOI: https://doi.org/10.31004/basicedu.v6i1.1864

\section{HASIL DAN PEMBAHASAN}

Dalam pelaksanaan kegiatan pembelajaran daring (online) tentunya terdapat kendala yang dihadapi oleh orang tua karena transisi dari pembelajaran tatap muka ke pembelajaran daring juga memerlukan waktu. selama ini siswa yang terbiasa menggunakan sistem tatap muka untuk pembelajaran bingung dengan sistem yang baru. Selain itu, sebagian besar orang tua tidak berpartisipasi dalam kegiatan belajar anak mereka, tetapi sekarang mereka perlu berpartisipasi penuh dalam pembelajaran jarak jauh. Seperti opini (Putri, 2021) "Many problems occurred during the implementation of the distance learning program during the COVID19pandemic. So far, students who are accustomed to learning with the face-to-face system are confused with this new system. Moreover, most parents are not involved in the learning activities of their children, but now they have to be fully involved during distance learning. Never mind skills, they are not mentally ready'. Dari hasil penelitian yang dilakukan di MI AL Maarif Doyo mengenai kendala guru dalam mendampingi anak selama belajar daring, menunjukkan beberapa kendala yang perlu dievaluasi dan disikapi oleh pihak orang tua maupun guru di sekolah. Dalam pengumpulan data informasi yang bersumber dari orang tua, dengan menggunakan 3 teknik yaitu observasi, wawancara dan angket. Keterlibatan orang tua merupakan faktor penting untuk pencapaian siswa dalam pengaturan sekolah tradisional. Dukungan orang tua telah menunjukkan kontribusi yang signifikan terhadap keberhasilan peserta didik dalam lingkungan belajar virtual. Secara umum ada beberapa peran orang tua seperti menjaga dan memastikan anak hidup bersih dan sehat, mendampingi pergi bersekolah, bermain dengan anak, menjadi teladan bagi anak, bersoliasasi di rumah, menciptakan lingkungan yang nyaman bagi anak, menjalin komunikasi yang erat dengan anak, dan memberikan pengawasan kepada anggota keluarga. Selain itu jika ditinjau dari pendampingan saat pembelajaran, peran dan kendala orang tua dapat dijabarkan sebagai berikut :

\section{Peran dan Kendala Orang Tua Dalam Mendampingi Anak Selama Pembelajaran Daring a) Menggunakan Media Pembelajaran Daring}

Penggunaan media pembelajaran menjadi hal yang penting saat pembelajaran baik pembelajaran tatap muka maupun daring. Saat pembelajaran daring, orang tua diharapkan bisa menyediakan media pembelajaran yang memadai. Media pembelajaran selalu berkaitan dengan sarana dan prasarana belajar. Lazim ini media yang sering digunakan orang tua dalam mendampingi anak belajar adalah media buku dan handphone. Hal ini seperti dari hasil wawancara orang tua di MI Al Maarif Doyo. Berdasarkan hasil observasi, wawancara, dan angket, semua orang tua menggunakan media handphone dalam mendampingi anak belajar daring. Beberapa juga ada yang menggunakan media belajar tambahan seperti buku dan papan tulis. Sementara itu dalam pelaksanaan pendampingan belajar saat menggunakan media belajar, beberapa orang tua di MI Al Maarif Doyo mengalami kendala yaitu jaringan atau sinyal handphone tidak stabil. Hal tersebut seperti penelitian oleh Leli Efriana yang mengungkapkan “ doesn't stop there. Even though the internet is in their hands, students still face difficulty accessing the internet network because of the places they live. A research carried out by Nashruddin, Alam, and Tanasy (2020) confirms that some students live in rural areas that are not covered by the internet. In addition, their cellular network is sometimes unstable, due to the geographical location which is quite far from the signal coverage" (Efriana, 2021, p. 40). Hal tersebut berarti beberapa siswa mengalami kesulitan mengakses jaringan internet dikarenakan area tempat tinggalnya yang tidak terjangkau oleh sinyal. Hal ini dibuktikan dari hasil observasi yang menunjukkan sebanyak 5 orang tua saat mendampingi anak belajar mengalami kesulitan sinyal sehingga menyebabkan tugas lama terikim kepada guru hal tersebut didukung oleh wawancara orang salah satu orang tua kelas VI yang bernama Amat Nasiri yang mengungkapkan bahwa : "mengirimnya lama karena sinyal apalagi jika tugasnya membuat video"

Dan tentang adanya kesulitan sinyal atau jaringan didukung dengan hasil angket dimana sebanyak 5 orang tua sering kali merasa terkendala oleh sinyal. Selain dari pihak orang tua, pihak guru kelas VI pun mengungkapkan bahwa beberapa orang tua atau siswa yang terkendala sinyal berikut ini : "banyak siswa yang 
mengeluh karena sinyal lemot dan sering telat mengikuti pembelajaran di grup dan juga banyak siswa yang tidak fast respon".

Selain itu kepala sekolah juga mengungkapkan bahwa salah satu kendala yang dihadapi orang tua adalah susahnya sinyal. Adapun penyebab hal ini kemungkinan dapat disebabkan oleh kartu yang dipakai tidak cocok dengan wilayah tempat tinggalnya. Jadi perlu adanya alternative solusi pemecahan masalah.

\section{b) Memberikan Stimulus Belajar Pada Anak}

Pemberian stimulus atau rangsangan belajar pada anak sangatlah penting, hal ini bertujuan agar anak mau belajar dengan semangat dan atas kemauan mereka sendiri. Dalam memberikan stimulus belajar kepada anak ada beberapa cara seperti memeperkaya hidup anak dengan bahasa, musik, dan aktivitas fisik, memicu rasa ingin tahu anak, memberikan kesempatan berefleksi dll. Berdasarkan hasil observasi, wawancara, dan angket terhadap orang tua di MI Al Maarif Doyo menunjukkan dalam menstimulus belajar anak, orang tua menggunakan reward seperti hadiah baik berupa barang ataupun kegiatan yang disukai siswa seperti bermain dll. Sementara itu dalam pelaksanaanya dari hasil penelitian menunjukkan bahwa kendala yang dihadapi orang tua saat menstimulus anaknya untuk belajar secara garis besar adalah anak tidak semangat belajar, anak tidak fokus belajar, dan mood anak tidak stabil. Jadi intinya kendala yang dihadapi orang tua adalah sikap anak itu sendiri yang masih labil untuk memiliki kemauan belajar sendiri. Hal tersebut didukung oleh hasil observasi yang menunjukkan bahwa sebanyak 7 orang tua banyak yang terlihat kesulitan megatur anak untuk mau dan semangat belajar daring. Hasil dari wawancara salah satu orang tua kelas V menunjukkan bahwa anak susah untuk diberikan stimulus karena memang susah diatur seperti kutipan wawancara berikut : "Anak tidak mau belajar malah menangis kalau dipaksa".

Selain dari hasil observasi dan wawancara, hasil angket pada aspek menumbuhkan minat belajar pun menunjukkan bahwa sebanyak 5 orang tua sering dan 2 orang tua selalu merasa kesulitan dalam menumbuhkan minat belajar atau memberi stimulus kepada anak. Dari pihak guru kelas V mengungkapkan hal yang berkaitan bahwa kendala yang diahapi siswa ataupun orang tua adalah anak manja dan tidak mau belajar seperti kutipan wawaancara berikut :

"Kendala dari siswa yaitu kurang paham dengan materi yg disampaikan dalam pembelajaran daring begitupun orang tua saat mendampingi anak dan anak anak lebih suka bermain daripada belajar beberapa anak pun malah manja dan tidak mau belajar". Dari pihak kepala sekolah mengungkapkan bahwa salah satu kendala yang dihadapi orang tua adalah anak yang sulit diatur saat dirumah, seperti kutipan wawancara berikut :

"ada banyak mbak, kalau untuk guru kendalanya adalah cara menilai yang harus melihat hp terus dan anak tidak mengumpulkan tugas sedangkan orang tua banyak yang mengeluh tentang sinyal yang lambat dan anak saat di rumah susah diatur oleh orang tua kendala yang lain seperti orang tua tidak paham pelajaran anak disekolah, dan kendala utamanya adalah kesibukan bekerja orang tua itu sendiri "

\section{c) Mengontrol Waktu Belajar Anak}

Dalam kegiatan anak sehari - hari perlu adanya pengontrolan waktu kegiatan. Hal ini bertujuan agar teratur dalam melakukan kegiatan. Jadi harapannya anak bisa membedakan kapan waktu belajar, bermain, ibadah dll. Dalam pelaksanaanya cara yang umum digunakan orang tua adalah dengan membuat jadwal kegiatan untuk anak yang di didalamnya ada waktu kegiatan untuk belajar. Jadi orang tua di di MI Al Maarif Doyo membimbing anak untuk tidak boleh bermain sebelum waktu dan tugas belajarnya selesai dikerjakan. Sementara itu kendala yang dihadapi orang tua adalah kesibukan orang tua, anak menyepelakan waktu belajar dan anak lebih suka bermain daripada belajar hal tersebut seperti. Hal tersebut seperti pendapat berikut "There are some parents who statethat their children play more than study at home. It makes parents quite difficult to organize children's learning activities and in order to overcome this problem, some parents direct the 
children to create daily scheduled activities, including a studyschedule, break time and play time'" (Novianti \& Garzia, 2020) dari kutipan tersebut berarti beberapa orang tua yang menyatakan bahwa anak-anak mereka lebih banyak bermain daripada belajar di rumah. Pada intinya kendala yang dihadapi adalah sama dengan kendala saat memberikan stimulus belajar kepada anak.

\section{d) Menciptakan Suasana Kekeluargaan Yang Mendukung}

Suasana kekeluargaan yang mendukung dapat diartikan bahwa hubungan antar anggota keluarga berjalan secara harmonis dan saling menyayangi. Peran orang tua adalah menciptakan suasana tersebut agar anak dapat belajar secara nyaman dan menyenangkan hal tersebut sangatlah penting agar kegiatan belajar dapat berjalan dengan optimal. Suasana belajar yang nyaman juga akan membuat anak tertarik untuk mempelajari hal yang baru serta anak akan lebih nyaman dalam belajar. Suasana nyaman yang dimaksud adalah suasana yang tenang dan tidak adanya masalah dalam keluarga. Maka dari itu orang tua memiliki peran penting dalam menciptakan suasana pembelajaran yang nyaman, kondusif dan menyenangkan. Berdasarkan hasil penelitian, peran orang tua dalam menciptakan suasana belajar yang kondusif adalah menciptakan suasana yang mendukung dengan menceritakan dongeng, memberikan permainan yang menarik, dan mengajak teman sejawat untuk belajar bersama. Adapun kendala yang dihadapi orang tua adalah orang tua kadang merasa lelah, dan mood (suasana hati) anak yang tidak mendukung sehingga keberhasilan pembelajaran daring dapat terkendala.

\section{e) Mengawasi Perkembangan Anak}

Pengawasan terhadap perkembangan anak merupakan peran penting yang harus dilakukan oleh orang tua. Dengan mengawasi perkembangan anak, orang tua dapat mengetahui sejauh mana progress dan kendala yang dihadapi anak dalam masa perkembangan. Dari sisi konteks belajar, orang tua di MI Al Maarif Doyo cara yang digunakan dalam mengawasi perkembangan belajar anak adalah dengan cara bertanya pada guru, memantau dan membatasi anak untuk bergaul dan bermain dengan temannya, dan mengajak anak untuk selalu berkomunikasi dengan orang tuanya dan untuk progress hasil belajar dengan melihat nilai rapor. Adapun dalam menjalankan peran ini, orang tua di MI Al Maarif Doyo mengalami kendala yaitu kesibukan orang tua yang tidak bisa untuk selalu mengawasi perkembangan anak. Hal tersebut seperti hasil observasi dan angket yang menunjukkan sebanyak 6 orang tua sering terlihat dan merasa kesulitan mengawasi perkembangan anak yang diakibatkan oleh keterbatasan waktu untuk mendampingi seperti yang diungkapan salah satu orang tua siswa kelas IV dengan kutipan wawancara berikut :

"Kendalanya kesibukan bekerja yang kadang menghambat saya untuk bisa bersama belajar dan mendampingi anak"

Dari hasil wawancara dengan guru bahwa guru kelas IV juga mengungkapkan bahwa salah satu kendala yang sering diadapi orang tua adalah kesibukan orang tua itu sendiri seperti yang diungkapkan oleh guru kelas IV sebagai berikut :

"Kendala Ada anak yg gak pegang hp, kuota, sulit sinyal dan penyebabya kemungkinan diakarenakan kesibukan orang tuanya"

Kepala sekolah saat diwawancarai juga mengungkapkan hal yang serupa bahwa kendala yang sering diahadapi oleh anak atau orang tua adalah orang tua terkadang tidak bisa mendampingi anak karena harus berkerja untuk memenuhi kebutuhan. Seperti kutipan wawancara berikut ;

"ada banyak mbak, kalau untuk guru kendalanya adalah cara menilai yang harus melihat hp terus dan anak tidak mengumpulkan tugas sedangkan orang tua banyak yang mengeluh tentang sinyal yang lambat dan anak saat di rumah susah diatur oleh orang tua kendala yang lain seperti orang tua tidak paham pelajaran anak disekolah, dan kendala utamanya adalah kesibukan bekerja orang tua itu sendiri ” 
DOI: https://doi.org/10.31004/basicedu.v6i1.1864

\section{f) Melakukan Koordinasi dengan Guru}

Koordinasi merupakan hal yang penting bagi orang tua untuk mendapatkan informasi tentang perkembangan anak mengenai kegiatan belajarnya. Saat pembelajaran daring, koordinasi perlu dilakukan karena tugas, dan materi yang disampaikan oleh guru perlu dipahami orang tua agar bisa mengarahkan anaknya untuk belajar dan mengerjakan tugas. Cara yang dilakukan orang tua di MI Al Maarif Doyo seperti pada umumnya yaitu berkoordinasi melalui Whatsapp tentang informasi dari sekolah, materi pelajaran dan tugas yang harus dikerjakan anak. Adapun kendala yang dihadapi sama dengan kendala pada indikator lain yaitu sulitnya jaringan dan kesibukan orang tua itu sendiri karena harus bekerja.hal tersebut relevan dengan penelitian (Situmorang, 2018) berpendapat bahwa"' Parents are the ones who play an active role at home to teach their children to learn at home. Challenges faced by parents in online learning such as limitations and media resources, limited time, mastery of technology'. Pendapat tersebut artinya orang tua adalah pihak yang berperan aktif di rumah untuk mengajari anak-anaknya belajar di rumah. Tantangan yang dihadapi orang tua dalam pembelajaran online seperti keterbatasan dan sumber daya media, waktu yang terbatas, penguasaan teknologi (Alwafi Ridho Subarkah, 2018)

\section{g) Mendampingi Anak dalam Pengerjaan Tugas}

Dalam mengerjakan tugas daring, anak perlu didampingi agar dapat mengerjakan sendiri dan membimbingnya jika merasa kesulitan atau belum paham. Hal ini perlu dilakukan karena anak jika dibiarkan mengerjakan sendiri mayoritas anak belum paham hal ini dikarenakan pembelajaran daring yang dirasa kurang maksimal. Adapun peran yang dilakukan orang tua di MI Al Maarif Doyo adalah dengan mendampingi anaknya. Adapun kendala yang dihadapi orang tua dalam mendampingi anak dalam pengerjaan tugas dan membimbingnya. Adapun kendala yang dihadapi adalah orang tua kurang memahami materi dan terkadang anak ngeyel tidak mau mengerjakan tugas yang diberikan oleh guru. Dari hasil observasi menunjukan bahwa sebanyak 6 orang tua kesulitan memahami materi pelajaran saat mendampingi anak belajar, begitu pun dengan hasil angket sebanyak 6 orang tua merasa sering kesulitan dalam memahami materi pelajaran. Hal tersebut seperti yang diungkapkan oleh salah satu orang tua siswa kelas $\mathrm{V}$ sebagai berikut :

"materinya susah karena sudah kelas 5 "

Selain itu dari hasil wawancara terhadap guru kelas V mengungkapkan bahwa materi yang diajarkan susah untuk dipahami orang tua, jadi kemungkinan orang tua akan susah untuk mendampingi anak dalam pengerjaan tugas seperti kutipan wawancara guru sebagai berikut :

"Kendala dari siswa yaitu kurang paham dengan materi yg disampaikan dalam pembelajaran daring begitupun orang tua saat mendampingi anak dan anak anak lebih suka bermain daripada belajar beberapa anak pun malah manja dan tidak mau belajar"

\section{h) Mendampingi Dalam Pengumpulan Tugas}

Tugas belajar adalah bentuk tanggung jawab serta kewajiban siswa atau anak dalam kegiatan pembelajaran baik pembelajaran tatap muka atau pembelajaran daring. Setelah tugas dikerjakan oleh anak, maka peran orang tua juga harus memastikan bahwa tugas harus dikumpulkan ke gurunya agar memperoleh nilai dan hal itu merupakan edukasi kepada anak untuk bertanggung jawab. Upaya atau peran orang tua di MI Al Maarif Doyo adalah dengan mendampingi anak untuk mengumpulkan tugas melalui Whatsapp dengan cara memfoto atau memvideo tugas. Selain itu orang tua juga memastikan tugas telah dikirim kepada guru di sekolah. Adapun kendala yang dihadapi adalah terkadang lupa belum mengumpulkan tugas, serta tugas yang diberikan tidak terbaca sehingga tidak mengumpulkan serta terkadang tugas tidak dikoreksi dan tidak dinilai serta sulitnya jaringan. 


\section{Solusi Dalam Mengatasi Kendala Orang Tua Dalam Mendampingi Anak Belajar}

Kendala dalam setiap kebijakan pastinya selalu ada. Akan tetapi hal tersebut dapat diminimalisir sekecil mungkin. Begitu pun dengan kebijakan pemerintah dalam menerapkan kebijakan pembelajaran daring yang menimbulkan beberapa kendala baik dari segi orang tua, guru, maupun siswa itu sendiri. Dari hasil penelitian dengan bebrapa metode pengumpulan data, peneliti menganbil beberapa garis besar permasalahan orang tua dalam mendampingi anak saat pembelajaran daring dan berikut alternatif solusi yang dapat diberikan oleh peneliti:

\section{a) Solusi Sulitnya Jaringan Handphone}

Jaringan atau sinyal handphone merupakan hal yang penting agar handphone dapat dioperasikan untuk pembelajaran, beberapa daerah di Indonesia masih banyak yang mengalami kendala kesulitan jaringan. Termasuk di daerah Doyo klaten, disana beberapa orang tua mengalami kendala jaringan yang berakibat orang tua tidak dapat mengumpulkan tugas anaknya dengan tepat waktu. Adanya jaringan yang sulit dapat disebabkan oleh beberapa factor seperti provider yang tidak sesuai ataupun wilayahnya yang terpencil. Hal tersebut seperti penelitian oleh Yolanda bahwa pembelajaran daring (online) juga terkendala dengan jaringan internet yang tidak stabil dan juga harga kuota yang sangat mahal selama masa pandemi. Letak rumah sisw juga berpengaruh pada koneksi internet. Ada yang berada di dataran tinggi yang mendapatkan koneksi lancar dan ada juga di dataran rendah yang terkadang menyebabkan jaringan internet tidak lancar (Yolanda, 2020). Maka dari itu solusi yang dapat diberikan dari peneliti adalah sebaiknya orang tua mengganti kartu handphone yang sesuai dengan wilayahnya agar pembelajaran daring dapat terlaksana dengan lancar.

\section{b) Solusi Dari Kendala Anak Tidak Mood Untuk Belajar}

Mood ataupun perasaan anak untuk mau belajar merupakan hal yang penting untuk diperhatikan oleh orang tua, karena mood akan mempengaruhi perilaku belajar anak. Orang tua saat mendampingi anak di rumah dapat menciptakan suasana yang nyaman agar anak minat untuk belajar walaupun tidak di sekolah. Metode bermain dapat dijadikan alternatif untuk mendampingi anak saat belajar daring. Karena kegiatan bermain menyenangkan dan bisa meningkatkan motivasi dan minat belajar anak. Selain daripada itu, dapat pula orang tua memberikan reward sebagai apresiasi atas kerja anak setelah melaksanakan kegiatan belajar di rumah. Reward merupakan penghargaan yang diberikan terhadap sesworang yang telah melakukan pencapaian tertentu dalam sebuah kegiatan berupa perilaku baik, rajin, prestasi dantekun (Puspitasari, 2016). Harapannya dengan pemberian reward dapat memotivasi anak untuk semangat dalam belajar daring.

\section{c) Solusi Dari Kesibukan Orang Tua}

Saat pembelajaran daring, peran orang tua untuk mendampingi anak merupakan peran yang penting dan harus diperhatikan, akan tetapi terkadang orang tua merasa terkendala karena kewajiban pekerjaan yang tidak bisa ditinggalkan. Disisi lain jika anak tidak didampingi saat belajar, anak akan semaunya sendiri. Maka solusi yang bisa dilakukan adalah meluangkan waktu untuk mendampingi anak belajar dengan bergantian dengan anggota keluarga yang lain. Pada masa pandemi corona, orang tua yang memiliki pekerjaan harus bia meluangkan waktu untuk memberikan motivasi dan mendampingi anak untuk belajar. Serta harus bisa mengatur waktu antara menyelesaikan pekerjaan dan mendampingi anak belajar dengann sebaik mungkin. (Astuti \& Harun, 2020). Meskipun begitu dengan adanya pendampingan dari orang tua juga akan berdampak terciptanya kekeluargaan yang harmonis antara orang tua dengan anak. Selain itu, dapat pula orang tua mengundang guru les private untuk mendampingi anak belajar agar saat pembelajaran daring materi pelajaran dapat dipahami oleh siswa. 
DOI: https://doi.org/10.31004/basicedu.v6i1.1864

\section{d) Solusi dari Anak Jenuh Belajar}

Strategi yang dapat diterapkan oleh orangtua terdiri dari yaitu: berteman dengan anak, menanamkan kegembiraan pada anak, mengadakan perlombaan dan memberikan hadiah bagi pemenang, memotivasi dan mendukung potensi anak, memberikan pujian dan sanjungan yang merupakan energi positif atas segala perbuatan yang sudah dilakukan oleh anak, bermain bersama anak, menumbuhkan rasa percaya diri anak, mengabulkan keinginan anak, melakukan pengulangan perintah dengan pengulangan berkalikali supaya perintah tersebut dapat tertanam di hati dan pikirannya, dan memberi reward (hadiah) serta punishment (ancaman) yang mendidik tanpa harus merusak mental anak, supaya anak tidak selalu mengharapkan sebuah hadiah kepada orang lain (Fauziah \& Nadlifah, 2021).

Secara garis besar cara mengatasi sebuah kejenuhan untuk anak usia dini dapat berupa mengalihkan kegiatan secara monoton dengan kegiatan yang berbeda, contohnya apabila anak sedang belajar dapat dialihkan dengan mempelajari hal-hal yang disekitarnya, sehingga anak tidak hanya belajar melalui media kertas, namun anak juga dikenalkan dengan permasalahan di lingkungan sekitarnya. Selain itu anak juga diajak untuk bermain atau jalan-jalan sebagai cara mengembalikan mood anak yang buruk, juga memberikan reward kepada anak apabila anak telah menyelesaikan tugasnya secara baik.

\section{e) Solusi Kurangnya Pemahaman Materi Orang Tua}

Kegiatan belajar mengajar online akan terkendala apabila materi yang disampaikan guru tidak dapat dipahami orang tua saat di rumah. Karena orang tua lah yang mendampingi anak secara langsung saat di rumah. Jadi orang tua harus bisa untuk menguasai materi pelajaran yang diberikan guru agar tujuan pendidikan dapat berjalan dengan lancer (Irma, Nisa, \& Sururiyah, 2019). Selain itu pentingnya pemahaman materi orang tua seperti yang diungkapkan Rasmitadila dkk "Parents must understand the material because parents help students to understand the subject matter in the SFH process. The situation becomes even more complicated if parents do not understand the subject matter, and the instructional process does not go according to the instructional strategies that a teacher has set" yang berarti orang tua harus memahami materi karena orang tua membantu siswa untuk memahami materi pelajaran dalam proses SFH. Situasi menjadi lebih rumit jika orang tua tidak memahami materi pelajaran, dan proses pembelajaran tidak berjalan sesuai dengan strategi pembelajaran yang telah ditetapkan guru (Aliyyah et al., 2020, p. 103). Hasil penelitian menunjukkan hasil bahwa pemahaman meteri oleh orang tua dalam mendampingi anak belajar dirumah dimasa pandemi ini menjadi kendala orang tua. Hal tersebut relevan dengan penelitian Cahyati yang mengungkapkan bahwa selama pembelajaran online, kebanyakan orang tua yang kurang dapat memahami materi pelajaran yang diberikan guru, mereka menganggap tugasnya terlalu sukar untuk dipahami sehingga mereka kesusahan untuk menjelaskan kepada anaknya (Cahyati \& Kusumah, 2020). Adapun solusi yang dapat diberikan oleh peneliti adalah mengundang guru privat untuk membantu orang tua dalam mengajarkan materi kepada siswa, karena jika tidak dilakukan pendampingan anak akan merasa kebingungan memahami materi pelajaran saat pembelajaran daring.

Dari hasil penelitian terdapat bebrapa kesesuaian antara penelitian ini dengan penelitian yang terdahulu (Wardani \& Aryza, 2020 ) diantaranya terdapat persamaan kendala dalam mendampingi anak belajar daring seperti : waktu pendampingan yang terbatas, orang tua kurang memahami materi pembelajaran dan susahnya jaringan handphone. Dalam penelitian, kendala yang dihadapi dari setiap sekolah pastinya berbeda - beda dan dari dari hasil pemaparan kendala diatas itulah yang terjadi pada orang tua di MI AL Maarif Doyo. Disisi lain dalam penelitian ini peneliti merasakan adanya banyak keterbatasan yang kedepannya perlu untuk dikembangkan lagi dalam rangka perkembangan keilmuan. 
DOI: https://doi.org/10.31004/basicedu.v6i1.1864

\section{PENUTUP}

Kesimpulan dari penelitian ini adalah bahwa kendala yang dihadapi oleh orang tua di MI AL Maarif Doyo meliputi : kendala jaringan sinyal, kendala mood anak tidak mau belajar, kendala kesibukan orang tua, kendala anak jenuh belajar dan kendala kurangnya pemahaman materi pelajaran oleh orang tua. Adapun solusi untuk jaringan yang sulit bisa dengan mengganti kartu yang sesuai dengan wilayahnya, sementara kendala anak tidak mood dan jenuh belajar dengan solusi memberikan permainan yang menarik saat belajar serta pemberian reward atau hadiah dan untuk kendala kurangnya pemahaman materi dapat dilakukan dengan menghadirkan guru bimbingan belajar atau sering disebut les tambahan.

\section{DAFTAR PUSTAKA}

Aliyyah, R. R., Reza, R., Achmad, S., Syaodih, E., Nurtanto, M., Sultan, A., Riana, A., Et Al. (2020). The Perceptions Of Primary School Teachers Of Online Learning During The Covid-19 Pandemic Period : A Case Study In Indonesia. Journal Of Ethnic And Cultural Studies, 7(2), 90-109.

Alwafi Ridho Subarkah. (2018). Online Learning And Its Challenges For Parents Ester, 151(2), 10-17.

Astuti, I. Y., \& Harun, H. (2020). Tantangan Guru Dan Orang Tua Dalam Kegiatan Belajar Dari Rumah Anak Usia Dini Pada Masa Pandemi Covid-19. Jurnal Obsesi: Jurnal Pendidikan Anak Usia Dini, 5(2), 1454-1463.

Cahyati, N., \& Kusumah, R. (2020). Peran Orang Tua Dalam Menerapkan Pembelajaran Di Rumah Saat Pandemi Covid 19. Jurnal Golden Age, 4(01), 4-6.

Dewi, W. A. F. (2020). Dampak Covid-19 Terhadap Implementasi Pembelajaran Daring Di Sekolah Dasar. Edukatif: Jurnal Ilmu Pendidikan, 2(1), 55-61.

Efriana, L. (2021). Problems Of Online Learning During Covid-19 Pandemic In Efl Classroom And The Solution. Journal Of English Language Teaching And Literature, 2(1), 39.

Fadillah, M. (2019). Buku Ajar Bermain \& Permainan Anak Usia Dini. Jakarta: Kencana.

Fauziah, N., \& Nadlifah, N. (2021). Jenuh Belajar: Strategi Orang Tua Dalam Membersamai Anak Belajar Di Masa Pandemi Covid-19. Golden Age: Jurnal Ilmiah Tumbuh Kembang Anak Usia Dini, 6(2), 98-108.

Fransiska. (2020). Peran Orang Tua Dalam Kegiatan Belajar Di Rumah Pada Masa Pandemi Covid-19 ( Studi Kasus Pada Anak Usia 5-6 Tahun ). Dunia Anak: Jurnal Pendidikan Anak Usia Dini, 3(1).

Irma, C. N., Nisa, K., \& Sururiyah, S. K. (2019). Keterlibatan Orang Tua Dalam Pendidikan Anak Usia Dini Di Tk Masyithoh 1 Purworejo. Jurnal Obsesi : Jurnal Pendidikan Anak Usia Dini, 3(1), 214.

Kurniati, E., Nur Alfaeni, D. K., \& Andriani, F. (2020). Analisis Peran Orang Tua Dalam Mendampingi Anak Di Masa Pandemi Covid-19. Jurnal Obsesi : Jurnal Pendidikan Anak Usia Dini, 5(1), 241.

Lilawati, A. (2020). Peran Orang Tua Dalam Mendukung Kegiatan Pembelajaran Di Rumah Pada Masa Pandemi. Jurnal Obsesi : Jurnal Pendidikan Anak Usia Dini, 5(1), 549.

Novianti, R., \& Garzia, M. (2020). Parental Engagement In Children's Online Learning During Covid-19 Pandemic. Journal Of Teaching And Learning In Elementary Education (Jtlee), 3(2), 117.

Puspitasari, R. (2016). Pengaruh Pemberian Hadiah (Reward) Terhadap Kemandirian Belajar Anak Di Tk Tunas Muda Karas Kabupaten Magetan Ta 2015/2016. Surakarta: Uns.

Putri, R. E. (2021). Parents' Perception On "Belajar Dari Rumah" Progam For Elementary Students. Etude: Journal Of Educational Research, 1(2), 41-49.

Sabiq, A. F. (2020). Kendala Orang Tua Mendampingi Anak Belajar Di Rumah Dalam Menghadapi Situasi Covid 19. Civic-Culture: Jurnal Ilmu Pendidikan Pkn Dan Sosial Budaya, 4(1), 1-7. Retrieved From Http://194.59.165.171/Index.Php/Cc/Article/View/336\%0ahttps://Www.Liputan6.Com/News/Read/4227 077/Update-Corona-Selasa-14- 
286 Analisis Kendala Orang Tua dalam Mendampingi Anak Selama Pembelajaran Daring di Madrasah Ibtidaiyah - Maulia Isna Choirunisa, Zaenal Abidin

DOI: https://doi.org/10.31004/basicedu.v6i1.1864

Siahaan, M. (2020). Dampak Pandemi Covid-19 Terhadap Dunia Pendidikan. Jurnal Kajian Ilmiah, 1(1), 7380 .

Syarifudin, A. S. (2020). Impelementasi Pembelajaran Daring Untuk Meningkatkan Mutu Pendidikan Sebagai Dampak Diterapkannya Social Distancing. Jurnal Pendidikan Bahasa Dan Sastra Indonesia Metalingua, $5(1), 31-34$.

Wardani, A., \& Ayriza, Y. (2020). Analisis Kendala Orang Tua Dalam Mendampingi Anak Belajar Di Rumah Pada Masa Pandemi Covid-19. Jurnal Obsesi : Jurnal Pendidikan Anak Usia Dini, 5(1), 772.

Yolanda, S. (2020). Problematika Guru Dalam Pelaksanaan Kelas Daring (Online) Selama Masa Pandemi Covid-19 Pada Pembelajaran Tematik Siswa Kelas Iv Sekolah Dasar Negeri 22/Iv Kota Jambi. Jambi: Universitas Islam Negeri Sulthan Thaha Saifuddin Jambi. 